\title{
PELAKSANAAN PROGRAM TAX AMNESTY DALAM RANGKA MENINGKATKAN KEPATUHAN WAJIB PAJAK BADAN
}

(Studi Empiris terhadap Pelaksanaan Program Tax Amnesty 2016 - 2017)

\author{
Ira Murweni dan Gunardi \\ Politeknik Piksi Ganesha, Bandung \\ irapur@gmail.comdan goenhadis@gmail.com
}

\begin{abstract}
Tax Amnesty is one type of government policy that is used to accelerate economic growth and restructuring through the transfer of assets, which will affect domestic liquidity improvements, improve rupiah exchange rate, decrease interest rates, and increase investment, and increase tax revenues, others will be used for development financing. This study aims to measure the extent to which the success of the tax amnesty program implemented by the Government of the Republic of Indonesia during the period 2016 - 2017 in order to improve compliance with corporate taxpayers. The research method used in this research is quantitative descriptive by using secondary data that is the amount of tax amnesty fund receipt during Period I: from the date of enactment until September 30, 2016; Period II: From October 1, 2016 to December 31, 2016, and Period III: from 1 January 2017 to 31 March 2017 and the amount of corporate and personal taxpayers attending the program.Tests conducted on the amount of tax agencies that make the redemption of property and the number of applicant's tax amnesty program with the amount of tax amnesty and tax revenue in the same period. While the analysis of research data used is multiple linear regression analysis at a significant level $\alpha=0.05$ with the number of samples as many as 32 secondary data processed with SPSS software version 21 for Windows. Results The results of the t-independent test show that the implementation of the tax amnesty program is generally effective in improving taxpayer compliance.
\end{abstract}

Keywords: Tax Amnesty, Redemtion of Treasure, Agency Taxpayer

\section{A. PENDAHULUAN}

Membangun sebuah negara bukanlah hal yang mudah bagi pemerintah negara manapun di dunia ini. Persoalan pembangunan negara banyak dipengaruhi oleh faktor-faktor geografis, demografis, sumber daya alam, sosial-ekonomi, budaya, ras dan agama, juga kemampuan pemerintah dalam mengelola keuangan negara guna mengembangkan seluruh potensi yang dimilikinya agar mampu menciptakan kemakmuran dan kesejahteraan rakyatnya.

Pajak merupakan salah satu elemen penting pendapatan negara yang menerapkan sistem ekonomi kapitalisme. Terlepas dari sistem pemerintahan negara manapun, pajak merupakan topik utama semua negara dalam upaya mendapatkan sumber pembiayaan untuk membangun negaranya masing-masing.

Di Indonesia sendiri, pemerintah menempatkan Penerimaan Pajak sebagai akun utama di dalam penyusunan Rencana Anggaran Penerimaan dan Pengeluaran Negara (RAPBN) dan Anggaran Penerimaan dan Pengeluaran Negara (APBN) yang setiap tahunnya akan dilaporkan oleh Presiden RI dalam Rapat Paripurna DPR-MPR RI sebagai bentuk pertanggungjawaban lembaga eksekutif kepada parlemen.

Sistem self-assessment yang diberlakukan Pemerintah RI merupakan upaya untuk membangun kesadaran masyarakat dalam membayar pajak kepada negara. Seseungguhnya, ditinjau dari sisi positifnya, sistem self-assessement mampu berikan efek edukasi dan cermin sikap persuasif pemerintah bagi masyarakat dalam menumbuhkan sifat taat pajak atau kepatuhan pajak. Namun dalam kenyataannya, sistem tersebut sering kali dimanfaatkan oleh masyarakat untuk melakukan hal-hal yang mengarah pada penghinaran pajak hingga berujung pada manipulasi pajak. 
Kepatuhan pajak ang pada dasarnya dapat dibangun melalui sistem self-assesement tersebut, pada memunculkan berbagai persoalan yang harus mampu diselesaikan oleh pemerintah. Salah satu upaya pemerintah untuk terus membangun kesadaran dan kepatuhan masyarakat dalam membayar pajak adalah dengan mluncurkan program mengampunan pajak (tax amnesty) pada tanggal 28 Juli 2016 yang dituangkan di dalam UU No. 11 Tahun 2016 tentang Pengampunan Pajak.

Alasan lain pemerintah dalam penerapan undang-undang tax amnesty tersebut adalah banyaknya dana yang tersimpan di luar negeri dan kurangnya penerapan teknologi informasi database perpajakan nasional menjadikan dorongan bagi pemerintah untuk melakukan reformasi pajak. Kondisi kerugian pajak (tax loss) di Indonesia tersebut dapat dilihat dari rendahnya angka tax ratio ${ }^{1}$ Indonesia yang meskipun dari tahun ke tahun menunjukkan peningkatan, namun dibandingkan dengan negaranegara ASEAN dimana berdasarkan data dari Direktorat Jendral Pajak, tax ratio Indonesia dalam kurun waktu 2002-2012, menunjukkan tren yang fluktuatif. Tax ratio cenderung meningkat dalam periode 2002-2012 dari 11,5\% hingga mencapai 13,3\%. Namun pada tahun 2009 terjadi penurunan tajam ke posisi $11,1 \%$ sebelum kembali mengalami kenaikan yang konsisten pada periode 2010-2012 hingga mencapai 11,9\%. Menurut data IMF, rasio penerimaan pajak aktual terhadap PDB pada tahun 2010 sebesar 11,06 persen, padahal kapasitas pajak diperkirakan sekitar 21,5 persen dari PDB.

Indonesia sendiri untuk penghitungan tax ratio menggunakan metode pertama dimana penerimaan pajak pusat dibagi PDB dikarenakan selama ini APBN menggunakan metode seperti itu, namun ketika tax ratio indonesia dibandingkan dengan negara lain menggunakan pendekatan data yang dianut oleh OECD sesuai himbauan Direktorat Jenderal Pajak, maka tax ratio Indonesia tetap lebih rendah. Rata-rata di Asia Tenggara pada tahun 2011 adalah sebesar 12,24\% digambarkan dengan garis horizontal warna merah, sedangkan untuk tahun yang sama, posisi Indonesia berada pada 11,77\% Rasio tertinggi dimiliki oleh Thailand sebesar 17,55\% dan terendah adalah Myanmar (3,27\%). Jika kita lihat gambar di atas, tax ratio Indonesia hanya lebih tinggi dibandingkan dengan Myanmar dan Kamboja. Kondsi penurunan tax ratio ini terus berlanjut hingga tahun 2016 yaitu sebesar 11,50\%.

Sedangkan untuk potensi terjadinya penanaman modal di luar negeri (capital fliht), tercatat pada tahun 2004 saja, potensi pajak yang hilang dari kegiatan ekonomi di bawah tanah Indonesia mencapai sekitar 262 trilyun Rupiah².

Ketiga permsalahan perpajakan tersebut tentunya menjadi motivasi dan tugas berat bagi Pemerintah RI khususnya Direktorat Jendral Pajak untuk terus secara berkesinambungan melaksanakan reformasi pajak yang bertahap dan membutuhkan konsolidasi secara menyuluruh dengan berbagai kementrian terkait agar proses pendidikan pajak kepada masyarakat melalui program tax amnesty tersebut mampu menumbuhkan kesadaran dan kepatuhan masyarakat dalam membayar pajak baik oleh wajib pajak orang pribadi maupun wajib pajak badan.

Dari uraian permasalahan perpajakan tersebut di atas, maka dapat disimpulkan bahwa tujuan dari penelitian ini adalah untuk ;

a. Mengetahui pelaksanaan program tax amnesty di Indonesia selama periode 2016 hingga 2017.

b. Mengetahui pengaruh pelaksanaan program tax amnesty terhadapa kepatuhan pajak wajib pajak badan di Indonesia selama periode 2016 hingga 2017.

c. Mengetahui potensi-potensi lain dari dampak pelaksanaan tax amnesty khususnya pada jumlah penerimaan pajak selama periode 2016 hingga 2017.

\section{B. KAJIAN PUSTAKA}

\section{Definisi dan Pengertian Tax Amnesy}

Tax amnesty atau pengampunan pajak adalah kebijakan pemerintah di bidang perpajakan yang memberikan penghapusan pajak yang seharusnya terutang dengan membayar tebusan dalam jumlah tertentu yang bertujuan untuk memberikan tambahan penerimaan pajak dan kesempatan bagi Wajib Pajak yang tidak patuh menjadi Wajib Pajak patuh. Penerapan tax amnesty diharapkan akan mendorong peningkatan kepatuhan sukarela Wajib Pajak di masa yang akan datang (Devano, 2006:137) ${ }^{3}$. 
Sedangkan Sawyer $(2006)^{4}$ mengemukakan arti pengampunan pajak adalah "a tax amnesty generally involves providing previously noncompliant taxpayers with the opportunity to pay back-taxes on undisclosed income, without fear of penalities or prosecution".

Dari definisi tersebut dapat disimpulkan bahwa tax amnesty (pengampunan pajak) adalah program kebijakan Pemerintah yang memberikan kesempatan kepada wajib pajak untuk melunasi tunggakan pajaknya tanpa adanya sanksi administrasi guna meningkatkan kepatuhan wajib pajak dan penerimaan negara.

Ditinjau dari UU No 11 Tahun 2016 Tentang Pengampunan Pajak, definisi tax amnesty adalah sebuah penghapusan pajak yang seharusnya terutang, tidak dikenai sanksi administrasi perpajakan dan sanksi pidana di bidang perpajakan, dengan cara mengungkap Harta dan membayar Uang Tebusan yang sebagaimana diatur dalam Undang-Undang ini. Sedangkan menurut "PMK No. 118/PMK.03/2016" Tax Amnesty merupakan sebuah penghapusan pajak yang seharusnya terutang, tidak dikenai sanksi administrasi perpajakan dan sanksi pidana di bidang perpajakan, dengan cara mengungkap Harta dan membayar Uang Tebusan yang sebagaimana diatur dalam Undang-Undang Pengampunan Pajak.

Dari berbagai definisi tax amnesty tersebut dia atas dapat disimpulkan bahwa secara umum tax amnesty merupakan suatu kebijakan pemerintah yang diberikan kepada pembayar pajak (tax payer) tentang forgiveness / pengampunan pajak, dan sebagai ganti atas sebuah pengampunan tersebut pembayar pajak diharuskan untuk membayar uang tebusan. Mendapatkan sebuah pengampunan pajak artinya data laporan yang ada selama ini dianggap sudah diputihkan dan atas beberapa utang pajak juga dihapuskan.

\section{Tujuan dan Manfaat Tax Amnesty}

Adapun tujuan tax amnesty atau pengampunan pajak adalah (Darusalam, 2015) :

a. Meningkatkan penerimaan pajak dalam jangka pendek. Permasalahan penerimaan pajak yang stagnan atau cenderung menurun seringkali menjadi alasan pembenar diberikannya tax amnesty. Hal ini akan berdampak pada keinginan pemerintah untuk memberikan tax amnesty dengan harapan pajak yang dibayar oleh wajib pajak selama program tax amnesty akan meningkatkan penerimaan pajak.

b. Meningkatkan kepatuhan pajak dimasa yang akan datang. Kepatuhan pajak merupakan salah satu penyebab pemberian tax amnesty. Para pendukung tax amnesty umumnya berpendapat bahwa kepatuhan sukarela akan meningkat setelah program tax amnesty dilakukan. Hal ini didasari pada harapan bahwa setelah program tax amnesty dilakukan Wajib Pajak yang sebelumnya menjadi bagian dari sistem administrasi perpajakan, maka Wajib Pajak tersebut tidak akan bisa mengelak dan menghindar dari kewajiban perpajakannya.

c. Mendorong repatriasi modal atau aset. Kejujuran dalam pelaporan sukarela atas data harta kekayaan setelah program tax amnesty merupakan salah satu tujuan pemberian tax amnety. Dalam konteks pelaporan, data harta kekayaan tersebut, pemberian tax amnesty juga bertujuan untuk mengembalikan modal yang parkir di luar negeri tanpa perlu membayar pajak atas modal yang di parkir di luar negeri tersebut. Pemberian tax amnesty atas pengembalian modal yang di parkir di luar negeri ke bank di dalam negeri dipandang perlu karena akan memudahkan otoritas pajak dalam meminta informasi tentang data kekayaan wajib pajak kepada bank di dalam negeri

d. Transisi ke sistem perpajakan yang baru. Tax amnesty dapat di justifikasi ketika tax amnesty digunakan sebagai alat transisi menuju sistem perpajakan yang baru.

Apapun manfaat dalam menerapkan pengampunan pajak, terdapat beberapa hal yang menjadi pertimbangan pemerintah, yaitu (Devano, 2006:137-138);

a. Underground economy. Bagian dari kegiatan ekonomi yang sengaja disembunyikan untuk menghindarkan pembayaran pajak, yang berlangsung di semua negara, baik negara maju maupun negara berkembang. Kegiatan ekonomi ini lazimnya diukur dari besarnya nilai ekonomi yang dihasilkan, dibandingkan dengan nilai produk domestik bruto (PDB). Kegiatan ekonomi bawah 
tanah ini tidak pernah dilaporkan sebagai penghasilan dalam formulir surat pemberitahuan tahunan (SPT) Pajak Penghasilan, sehingga masuk dalam kriteria penyelundupan pajak (tax evasion)

b. Pelarian modal ke luar negeri secara ilegal. Kebijakan tax amnesty adalah upaya terakhir pemerintah dalam meningkatkan jumlah penerimaan pajak, ketika pemerintah mengalami kesulitan mengenakan pajak atas dana atau modal yang telah dibawa atau di parkir di luar negeri. Perangkat hukum domestik yang ada memiliki keterbatasan sehingga tidak dapat menjangkau Wajib Pajak yang secara ilegal menyimpan dana di luar negeri.

c. Rekayasa transaksi keuangan yang mengakibatkan kehilangan potensi penerimaan pajak. Kemajuan infrastruktur dan instrumen keuangan internasional seperti yang disebut sebagai tax heaven countries telah mendorong perusahaan besar melakukan illegal profit shifting ke luar negeri dengan cara melakukan rekayasa transaksi keuangan. Setelah itu, keuntungan yang dibawa ke luar negeri sebagian masuk kembali ke Indonesia dalam bentuk pinjaman luar negeri atau investasi asing. Transaksi tersebut disebut pencucian uang (money laundry). Ketentuan perpajakan domestik tak mampu memajaki rekayasa transaksi keuangan tersebut. Jika hal ini tidak segera diselesaikan, maka timbul potensi pajak yang hilang dalam jumlah yang signifikan. Tax amnesty diharapkan akan menggugah kesadaran wajib pajak dengan memberikan kesempatan baginya untuk menjadi Wajib Pajak patuh.

\section{Jenis-jenis Tax Amnesty}

Sawyer (2006) menyebutkan beberapa tipe pengampunan pajak (Tax Amnesty), yaitu:

a. Filling amnesty. Pengampunan yang diberikan dengan menghapuskan sanksi bagi Wajib Pajak yang terdaftar namun tidak pernah mengisi SPT (non-filers), pengampunan diberikan jika mereka mau mulai untuk mengisi SPT.

b. Record-keeping amnesty. Memberikan penghapusan sanksi untuk kegagalan dalam memelihara dokumen perpajakan di masa lalu, pengampunan diberikan jika Wajib Pajak untuk selanjutnya dapat memelihara dokumen perpajakannya.

c. Revision amnesty. Ini merupakan suatu kesempatan untuk memperbaiki SPT di masa lalu tanpa dikenakan sanksi atau diberikan pengurangan sanksi. Pengampunan ini memungkinkan Wajib Pajak untuk memperbaiki SPT-nya yang terdahulu (yang menyebabkan adanya pajak yang masih harus dibayar) dan membayar pajak yang tidak (missing) atau belum dibayar (outstanding). Wajib Pajak tidak akan secara otomatis kebal terhadap tindakan pemeriksaan dan penyidikan.

d. Investigation amnesty. Pengampunan yang menjanjikan tidak akan menyelidiki sumber penghasilan yang dilaporkan pada tahun-tahun tertentu dan terdapat sejumlah uang pengampunan (amnesty fee) yang harus dibayar. Pengampunan jenis ini juga menjanjikan untuk tidak akan dilakukannya tindakan penyidikan terhadap sumber penghasilan atau jumlah penghasilan yang sebenarnya. Pengampunan ini sering dikenal dengan pengampunan yang erat dengan tindak pencucian (laundering amnesty).

e. Prosecution amnesty. Pengampunan yang memberikan penghapusan tindak pidana bagi Wajib Pajak yang melanggar undang-undang, sanksi dihapuskan dengan membayarkan sejumlah kompensasi.

Sedangkan menurut Menurut Erwin Silitonga $(2006)^{5}$, terdapat empat jenis pengampunan pajak, yaitu:

a. Pengampunan hanya diberikan terhadap sanksi pidana perpajakan saja sedangkan kewajiban untuk membayar pokok pajak termasuk pengenaan sanksi administrasi seperti bunga dan denda tetap ada. Tujuan pengampunan ini adalah memungut dan menagih utang pajak tahun - tahun sebelumnya yang tidak dibayar atau dibayar tidak sesuai dengan peraturan perundang-undangan, sehingga penerimaan negara meningkat sekaligus jumlah wajib pajak bertambah.

b. Pengampunan pajak yang diberikan tidak hanya berupa penghapusan sanksi pidana, tetapi juga sanksi administrasi berupa denda. Tujuan dari pengampunan ini adalah dasarnya sama dengan jenis 1 (pertama), yang berbeda adalah jenis sanksi administrasi yang dikenakan oleh fiskus hanya 
sebatas bunga atas kekurangan pajak. Dengan demikian, model ini tetap harus membayar pokok pajak ditambah dengan bunga atas kekurangan pokok tersebut.

c. Pengampunan pajak diberikan atas seluruh sanksi, baik sanksi administrasi maupun sanksi pidana. Konsekuensi dari pengampunan jenis ini adalah wajib pajak hanya dikenakan kewajiban sebatas melunasi utang pokok untuk tahun-tahun sebelumnya tanpa dikenakan pidana. Dengan demikian pengampunan diberikan terhadap semua perbuatan yang dilakukan sebelum pemberian pengampunan pajak baik terhadap pelanggaran, yang bersifat adminitratif maupun pidana.

d. Pengampunan diberikan terhadap seluruh utang pajak untuk tahun-tahun sebelumnya dan juga atas seluruh sanksi baik yang bersifat administratif maupun pidana.

\section{Sejarah Tax Amnesty di Indonesia}

Dalam ulasan (Bagiada \& Darmayasa, 2016), Indonesia telah melaksanakan kebijakan tax amnesty sejak tahun 1964 yaitu di era pemerintahan Presiden Soekarno melalui Penetapan Presiden No. 5 tahun 1964. Tax Amnesty tahun 1964 ini berakhir pada 17 Agustus 1965. Saat itu, Penjelasan oleh Kepala Inspeksi Keuangan Jakarta Drs Hussein Kartasasmita yaitu, sampai bulan Juli Tahun 1965, jumlah dana yang diterima dari Tax Amnesty hanya sejumlah Rp 12 miliar. Jumlah tersebut sama jumlahnya dengan penerima dana SWI (Sumbangan Wajib Pajak Istimewa) Dwikora. Hal ini dianggap sangat aneh karena memang seharusnya penerimaan dana dari Tax Amnesty lebih besar jika dibandingkan dengan dana pungutan SWI Dwikora. Sejarah Tax Amnesty mencatat, rendahnya pemasukan dari dana hasil Tax Amnesty ini akibat dari banyaknya pungutan-pungutan lainnya, yaitu diantaranya Gekerev dan SWI Dwikora. Hal ini berakibat mengurangi daya bayar pajak para wajib pajak.

Tax Amnesty Tahun 1984 merupakan pelaksanaan kebijakan Tax Amnesty kedua. Sama halnya dengan tahun 1964, pada tahun 1984 Indonesia mencatat Sejarah Tax Amnesty melalui Keputusan Presiden (Kepres) No. 26 tahun 1984 Tentang Pengampunan Pajak dan Kepres No. 72 tahun 1984 tentang Perubahan Keputusan Presiden Nomor 26 Tahun 1984 Tentang Pengampunan Pajak. Tetapi, bukan untuk mengembalikan dana Revolusi, melainkan untuk mengubah sistem perpajakan di Indonesia dari official-assesment (besarnya jumlah pajak ditentukan oleh pemerintah) diubah ke selfassesment (besarnya pajak ditentukan oleh wajib pajak sendiri). Sarana prasarana yang kurang mendukung serta perumusan tujuan yang tidak jelas menyebabkan dua tax amnesty ini tidak berhasil (Ragimun, 2014) ${ }^{6}$. Ditambahkan oleh Tambunan $(2015)^{7}$ kegagalan dua kali ini karena kurangnya penegakan hukum (law-enforcement) yang tegas pasca tax amnesty. Sejarah Tax Amnesty di Indonesia tahun 1984 ini mengalami kegagalan karena memang sistem perpajakan belum terbangun.

Dari kegagalan dua kali penerapan program tax amnesty tersebut, maka pada program tax amnesty tahun 2016 yang lalu, pemerintah khususnya melalui kuasa pelaksana yaitu Direktorat Jendral Pajak telah mempersiapkan peraturan yang lebih tegas, pro-aktif, dan persuasif terhadapa pelaksanaan program tax amnesty yang ditujukan untuk : 1) melakukan pemutihan (pengampunan) pajak bagi wajib pajak perorangan dan badan yang belum melakukan pembayaran pajak hingga tahun 2016,2) repatriasi modal dari luar negeri ke dalam negeri, 3)meningkatkan kepatuhan pajak bagi wajib pajak orang pribadi dan badan, dan 4) membangun database wajib pajak yang lebih baik.

\section{Kepatuhan Pajak di Indonesia}

(Rosid \& Pendahuluan, n.d.) menjelaskan tentang kepatuhan pajak dalam 2 (dua) kategori yaitu pendekatan konseptual dan pendekatan operasional. Pendekatan konseptual, secara umum menekankan pada pentingnya kemauan wajib pajak untuk memenuhi kewajiban pajak tanpa hadirnya aktivitas penegakan hukum.Salah satu contoh definisi kepatuhan pajak dalam kategori ini adalah "the willingness of individuals and other taxable entities to act in accordance within the spirit as well as the letter of tax law and administration without the application of enforcement activity" (James \& Alley, 2004, p. 32) ${ }^{8}$. 
Sedangkan yang kedua adalah pendekatan operasional. Pendekatan ini memiliki kecenderungan untuk lebih fokus pada aspek administrative dari pemenuhan kewajiban pajak. Salah satu contoh definisi kepatuhan pajak di kelompok ini adalah "reporting all income and paying all taxes in accordance with the applicable law, regulations, and court decisions" (Alm, 1991, p. 577) ${ }^{9}$.

Dari sisi kegunaan, pendekatan konseptual memiliki kelemahan: ambiguitas. Misalnya, terdapat perbedaan pendapat mengenai apakah tindakan tax avoidance (menghindari pajak) perlu dimasukkan dalam definisi konseptual kepatuhan pajak. Meski dalam banyak kasus bisa ditentukan secara mudah bahwa tax avoidance adalah legal dan tax evasion (menyembunyi- kan pajak) adalah illegal, dalam beberapa kasus pertimbangan moral mutlak diperlukan untuk bisa memilahnya. Tentu ini menimbulkan masalah baru karena pertimbangan moral rentan subjektifitas. Fenomena inilah yang kemudian memunculkan istilah hibrid 'tax avoision'. Singkat kata, tingkat kepatuhan pajak tidak mudah untuk ditentukan, apalagi diukur, jika definisi konpseptual digunakan.

Pendekatan operasional bisa digunakan untuk menutupi kelemahan ini. Dengan pendekatan ini, tingkat kepatuhan pajak bisa secara relatif obyektif ditentukan dan diukur. Misalnya, untuk bisa dikatakan 'patuh' ideal, seorang wajib pajak setidaknya harus memenuhi empat kewajiban: "(i) to register for tax purposes; (ii) to file tax returns on time; (iii) to correctly report tax liabilities; and (iv) to pay taxes on time" (OECD, 2014, p. 60). Terlebih lagi, indikator ini bisa diterapkan baik di tingkat mikro (individual) atau makro (agregat). Misalnya, seorang Wajib Pajak mungkin bisa masuk kategori 'patuh sebagian' jika hanya memiliki Nomor Pokok Wajib Pajak (NPWP) dan menyampaikan Surat Pemberitahuan Pajak Penghasilan (SPT PPh), tapi tidak melaporkan secara jujur jumlah penghasilan dia yang sebenarnya dalam SPT PPh yang dia sampaikan ke otoritas pajak.

Di tingkat agregat kriteria ini juga bisa diterapkan dalam beberapa kategori. Pertama, tingkat kepatuhan untuk kategori registration (tingkat kepemilikan NPWP) bisa dilakukan dengan membandingkan data statistik jumlah individu atau entitas yang seharusnya sudah memiliki NPWP dengan data masterfile NPWP yang dimiliki oleh Direktorat Jenderal Pajak (DJP). Dalam hal ini, jumlah yang NPWP aktual dibagi dengan jumlah NPWP yang seharusnya akan menunjukkan registration ratio (istilah lain untuk kriteria ini adalah non-registration gap). Kedua, kategori filing (penyampaian SPT). Dalam kategori ini, jumlah SPT PPh yang secara aktual diterima DJP dibagi dengan jumlah SPT yang seharusnya diterima oleh DJP akan menunjukkan filing ratio (istilah lain untuk kriteria ini adalah non-filing gap). Yang ketiga adalah perbandingan antara jumlah penghasilan yang seharusnya dilaporkan dalam SPT PPh tetapi tidak dilaporkan dalam SPT PPh, yang seringkali disebut dengan underreporting gap. Menurut beberapa kajian, diantara ketiga kriteria ini yang paling sulit diukur adalah under- reporting gap.

Dalam upaya mendorong tumbuhnya kesadaran dan kepatuhan pajak wajib pajak orang pribadi dan wajib pajak badan, program tax amnesty tahun 2016 ini memberikan banyak keuntungan untuk wajib pajak yaitu ;

a. Penghapusan pajak yang seharusnya terutang

b. Tidak dikenai sanksi administrasi dan sanksi pidana perpajakan

c. Tidak dikenakan pemeriksaan, pemeriksaan bukti permulaan, dan penyidikan

d. Penghentian proses pemeriksaan, pemeriksaan bukti permulaan, dan penyidikan

e. Jaminan kerahasiaan yaitu data pengampunan pajak tidak dapat dijadikan dasar penyelidikan dan penyidikan tindak pidana apapun.

f. diberikan kepada setiap WP, yaitu orang pribadi, badan, pengusaha,

Tax Amnesty ini diberikan kepada pembayar pajak dengan omset tertentu dan orang pribadi atau badan yang belum ber-NPWP Pembebasan balik nama untuk harta tambahan.

\section{METODOLOGI PENELITIAN}

Penelitian ini menggunakan metode pendekatan deskriptif. Metode deskriptif adalah meode penelitian yang dilakukan untuk mengetahui nilai variable independen, baik satu variabel maupun lebih tanpa membandingkan atau menghubungkan dengan variabel lain (Sugiyono dalam Adelina, n.d.) ${ }^{10}$, melalui analisis tingkat kepatuhan pajak dan penerimaan pajak sebelum dan sesudah penerapan tax 
amnesty. Guna menghasilkan penelitian dan analisis yang tepat, penulis banyak melakukan kajian pustaka dari berbagai sumber yang berkaitan dengan penerapan tax amnesty baik berupa artikel, jurnal, peraturan pemerintah, undang-undang, dan berita nasional.

\section{HASIL DAN PEMBAHASAN}

(Jamil, 2017)menjelaskan di dalam Peraturan Menteri Keuangan Nomor 192/PMK.03/2007 bahwa seorang wajib pajak yang dikatakan memiliki kepatuhan pajak apabila memenuhi kriteria berikut yaitu ;

a. Apabila tepat waktu dalam menyampaikan SPT.

b. Tidak memiliki tunggakan pajak untuk semua jenis pajak kecuali apabila telah memperoleh izin untuk melakukan angsuran atau penundaan pembayaran pajak.

c. Laporan keuangan diaudit oleh auditor independen atau lembaga pemerintah yang berwenang melakukan pengawasan keuangan dan memperoleh pendapat wajar tanpa pengecualian selama tiga tahun berturut- turut.

d. Tidak pernah mendapatkan pidana karena melakukan tindak pidana di bidang perpajakan dan sudah ditetapkan oleh putusan pengadilan serta memiliki kekuatan hukum tetap selama lima tahun terakhir.

Dalam sebuah acara seminar Menteri Keuangan,Sri Mulyani menilai bahwa dalam beberapa tahun terakhir penerimaan pajak masih rendah. Tidak hanya penerimaan pajak tetapi rasio pajak juga belum optimal. Hal ini disebabkan karena rendahnya kepatuhan penyampaian pajak wajib pajak di Indonesia (http://www.kemenkeu. go.id, 2016). Data bulan Maret tahun 2016 menyebutkan bahwa hingga tahun 2015, jumlah wajib pajak yang terdaftar dalam sistem administrasi Direktorat Jenderal Pajak (DJP) mencapai 30.044.103 WP, yang terdiri atas 2.472.632 WP Badan, 5.239.385 WP Orang Pribadi (OP) Non Karyawan, dan 22.332.086 WP.OP Karyawan dengan jumlah tebusan sebesar 112,710 trilyun.

Sedangkan menurut data Badan Pusat Statistik (BPS), hingga tahun 2013, jumlah penduduk Indonesia yang bekerja mencapai 93,72 juta orang. Artinya baru sekitar 29,4\% dari total jumlah orang pribadi pekerja dan berpenghasilan di Indonesia yang mendaftarkan diri atau terdaftar sebagai WP. Dari total WP tersebut sebanyak 18.159.840 WP yang wajib melaporkan SPT. Dari total WP yang wajib melaporkan SPT, WP yang melaporkan SPT berjumlah 10.945.576 Wajib Pajak.

Data 30 April 2016 Direktorat Jenderal Pajak (DJP) mencatat jumlah wajib pajak yang melaporkan Surat Pemberitahuan (SPT) tahun pajak penghasilan (PPh) hingga 30 April 2016 sebanyak 11,67 juta. Angka itu meningkat 13\% dibandingkan dengan realisasi SPT periode yang sama tahun lalu 10,32 juta wajib pajak (WP). Namun jika dibandingkan dengan target 14,6 juta SPT yang ditetapkan DJP, realisasi pelaporan SPT pada akhir april 2016 yaitu 83,3 persen atau kurang 2,93 juta SPT. Dan sampai akhir periode III program Tax Amnesty yaitu per 31 Maret 2017, tercatat jumlah tebusan pengampunan pajak adalah sebesar 141,232 trilyun Rupiah.

Dari data diatas jumlah wajib pajak yang wajib menyampaikan SPT 19.333.565 WP, hanya 395.182 wajib pajak yang menjadi peserta tax amnesty. Sehingga jika dijumlahkan antara WP yang menyampaikan SPT hingga 30 April 2016 dengan peserta tax amnesty didapat angka 12.065.186, sehingga tingkat kepatuhan pajak WP akhir periode kedua tax amnesty 30 september yaitu $62,41 \%$ atau hanya meningkat 2,15\% dengan jumlah tebusan sebesar 141,232 trilyun Rupiah. Hal ini menandakan bahwa penerapan tax amnesty pada periode kedua ternyata belum mampu meningkatkan kepatuhan wajib pajak dalam memenuhi kewajiban pajaknya. Hasil pemetaan tingkat kepatuhan Wajib Pajak sampai dengan pelaksanaan program tax amnesty periode kedua dapat dilihat pada gambar 4.1 sebagai berikut ;

Gambar 4.1

Peta Daftar Peserta Ta Amnesty per Wilayah

Periode kedua

30 September 2016 


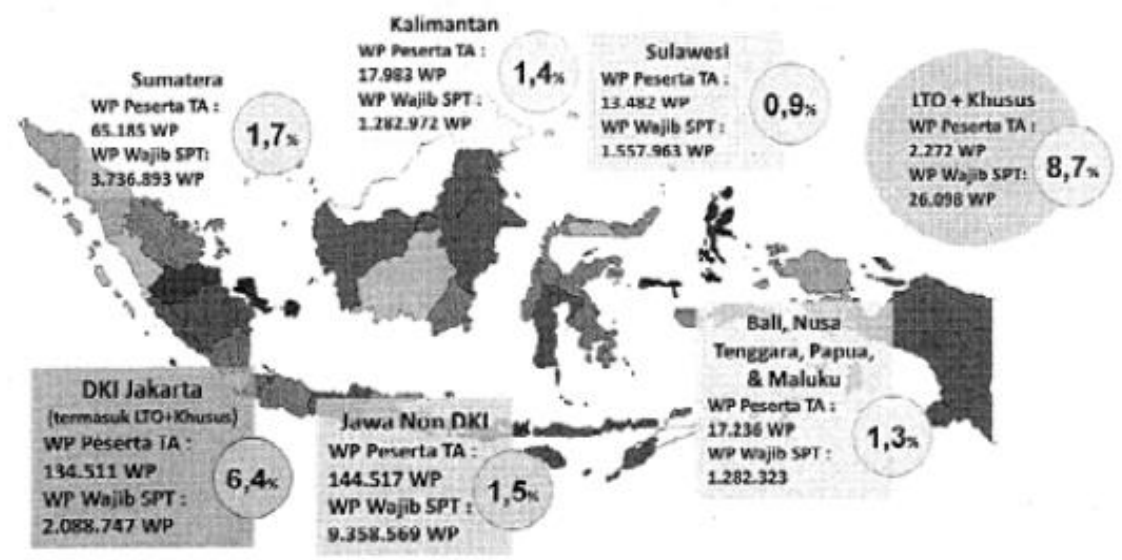

Sumber: Direktorat Jendral Pajak (“Keterangan Pers, 2016-10-14.pdf," n.d.)

Dan sampai akhir periode ketiga program Tax Amnesty yaitu per 31 Maret 2017, tercatat jumlah peserta tax amnesty mencapai 23.128.300 WP dengan jumlah tebusan pengampunan pajak adalah sebesar 135,347 trilyun Rupiah, sehingga tingkat kepatuhan WP pada akhir periode ketiga tax amnesty adalah sebesar $89,15 \%$ atau meningkat sebesar $27,26 \%$. Hal ini menunjukkann bahwa penerapan tax amnesty pada periode ketiga cukup mampu meningkatkan kepatuhan wajib pajak dalam memenuhi kewajiban pajaknya.

Secara tabulasi dapat dilihat dengan jelas perubahan tingkat kepatuhan pajak WP Badan selama tiga periode tax manesty yaitu sbb ;

Tabel. 4.1

Jumlah SPT, Jumlah Tebusan TA dan Tingkat Kepatuhan Wajib Pajak Badan

Tax Amnesty 2016-2017

\begin{tabular}{|c|c|c|c|}
\hline Periode & Jumlah SPT & $\begin{array}{r}\text { Jumah } \\
\text { Tebusan }\end{array}$ & $\begin{array}{c}\text { Tingkat } \\
\text { Kepatuhan }\end{array}$ \\
\hline I & 10.945 .576 & 112,710 trilyun & $60,26 \%$ \\
\hline II & 12.065 .186 & 141,232 trilyun & $62,41 \%$ \\
\hline III & 23.128 .300 & 135,347 trilyun & $89,15 \%$ \\
\hline
\end{tabular}

Sumber ; data diolah, 2017

Sedangkan hasil olah data penelitian terhadap 32 data sekunder yang diperoleh dari jumlah SPT, jumlah tebusan pengampunan pajak dan tingkat kepatuhan WP yang diolah dengan menggunakan sofware SPSS versi 21 dapat dijelaskan di dalam tabel 4.2 berikut ini ;

Tabel. 4.2

Persentase Pengaruh Jumlah SPT $\left(\mathrm{X}_{1}\right)$, Jumlah Tebusan Pengampunan Pajak $\left(\mathrm{X}_{2}\right)$ terhadap Kepatuhan Wajib Pajak Badan (Y)

\begin{tabular}{|l|l|c|l|l|}
\hline Uraian & $\mathbf{R}^{2}$ & $\begin{array}{c}\text { Signifikan } \\
\alpha= \\
0,05\end{array}$ & Uji t & Std. Error \\
\hline
\end{tabular}




\begin{tabular}{|c|r|r|l|l|}
\hline Pengaruh langsung $\mathrm{X}_{1}$ terhadap Y & 0,6473 & 0,14 & 46,553 & - \\
\hline Pengaruh langsung $\mathrm{X}$ 2 terhadap $\mathrm{Y}$ & 0,8517 & 0,11 & 59,56 & - \\
\hline Pengaruh $\mathrm{X}_{1}$ dan $\mathrm{X}_{2}$ terhadap $\mathrm{Y}$ & 0,7524 & 0,03 & 145,27 & - \\
\hline Variabel $\mathrm{X}_{1}$ & - & - & - & 8,929 \\
\hline Variabel $\mathrm{X}_{2}$ & - & - & - & 0,302 \\
\hline
\end{tabular}

Sumber ; data diolah penulis, 2017

Dari tabel 4.2 di atas dapat dijelaskan bahwa jika kedua variabel bebas diolah dengan metode regresi linear sederhana, maka jumlah SPT (Var. $\mathrm{X}_{1}$ ) berpengaruh terhadap Kepatuhan Wajib Pajak Badan (Var. Y) sebesar 0,6473 atau sebesar 64,73\% dengan tingkat signifikan sebesar 0,14 dan jumlah tebusan pengampunan pajak (Var. $\mathrm{X}_{2}$ ) sebesar 0,8517 atau sebesar 85,17\% dengan tingkat signifikan sebesar 0,11 .

Jika kedua variabel bebas $\mathrm{X}_{1}$ dan $\mathrm{X}_{2}$ diolah dengan menggunakan metode analisis Regresi Berganda, maka hasil yang diperoleh adalah kedua varibel bebas $\left(\mathrm{X}_{1}\right.$ dan $\left.\mathrm{X}_{2}\right)$ berpengaruh sebesar 0,7524 atau sebesar $75,24 \%$ terhadap variabel bergantungnya $(Y)$ pada tingkat signifikan 0,03 .

Jika hasil olah data statistik tersebut dipetakan di dalam Diagram Compliance Behaviour Outcome(Rosid \& Pendahuluan, n.d.) adalah sebaga berikut ;

Gambar 4.2

Type Kepatuhan Pajak yang Menjadi Sasaran

Program Tax Amnesty

\section{Compliance behaviour outcome}

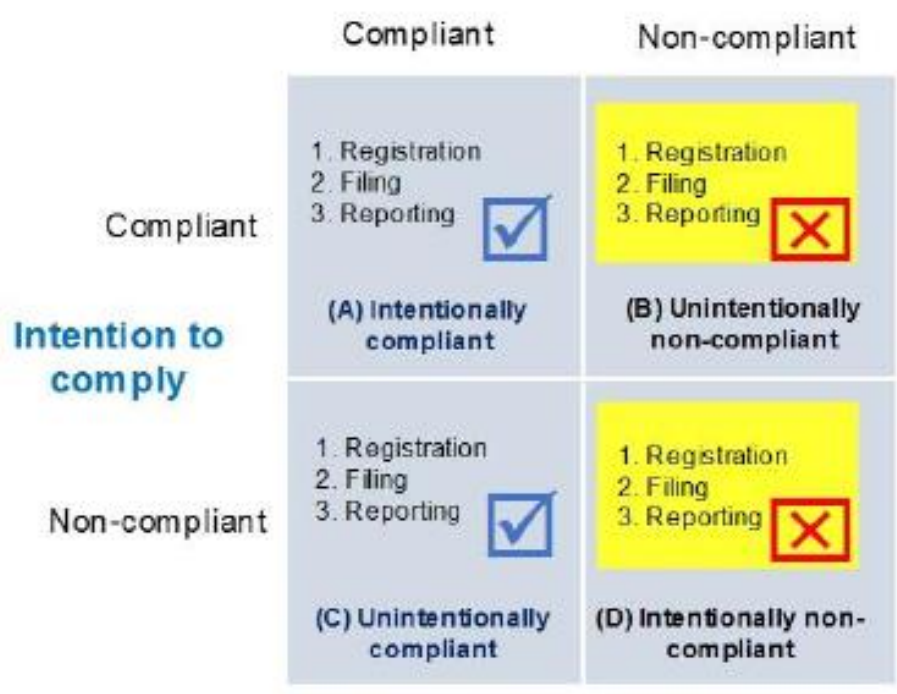

$=$ tergeted non-com pliance behaviour under tax amnesty

Gambar matrik di atas menjelaskan bagaimana program tax amnesty mengakomodir wajib pajak yang mungkin karena ketidaktahuan atau alasan lain secara tidak sengaja belum melaporkan harta dari penghasilan yang belum dikenakan pajak dalam SPT PPh (kuadran B3-unintentionally noncompliant) maupun wajib pajak yang di kuadran D3 (intentionally non-compliant), untuk pindah ke kuadran A3 dengan konsekuensi finansial yang rendah. Singkatnya, bisa dikatakan bahwa yang menjadi sasaran utama program tax amnesty ini, jika matriks perilaku kepatuhan digunakan sebagai acuan, adalah mereka yang berada di kuadran B (yang ketidakpatuhannya karena unsur 
ketidaksengajaan) dan D (yang memang sengaja tidak patuh) seperti terlihat dalam area kuning dalam Gambar 4.2.

Dengan kata lain, seorang yang wajib pajak yang tidak perlu memanfaatkan tax amnesty adalah mereka yang, entah sukarela atau terpaksa, telah menyelesaikan kewajiban pajak mereka. Sebagai contoh, seorang wajib pajak karyawan yang selama ini sudah dipotong dan memang sama sekali tidak memiliki penghasilan dari sumber lainnya namun, entah sengaja atau tidak sengaja, belum memasukkan harta tersebut ke dalam laporan SPT PPh, yang perlu dia lakukan adalah cukup melakukan pembetulan SPT PPh. Tidak perlu ikut program tax amnesty.

\section{E. KESIMPULAN}

Dari hasil penelitian yang dilakukan penulis secara empiris terhadap pelaksanaan pogram tax amesty tahun 2016 - 2017 dapat diketahui bahwa :

a. Jika kedua variabel bebas diolah dengan metode regresi linear sederhana, maka jumlah SPT (Var.

$\mathrm{X}_{1}$ ) berpengaruh terhadap Kepatuhan Wajib Pajak Badan (Var. Y) sebesar 0,6473 atau sebesar 64,73\% dengan tingkat signifikan sebesar 0,14 dan jumlah tebusan pengampunan pajak (Var. $\mathrm{X}_{2}$ ) sebesar 0,8517 atau sebesar $85,17 \%$ dengan tingkat signifikan sebesar 0,11 .

b. Jika kedua variabel bebas X1 dan X2 diolah dengan menggunakan metode analisis Regresi Berganda, maka hasil yang diperoleh adalah kedua varibel bebas (X1 dan X2) berpengaruh sebesar 0,7524 atau sebesar 75,24\% terhadap variabel bergantungnya $(\mathrm{Y})$ pada tingkat signifikan 0,03 .

c. Menurut peta Diagram Compliance Behaviour Outcome diperoleh kesimpulan bahwa type kepatuhan pajak yang menjadi sasaran program tax amnesty adalah mengakomodir wajib pajak yang mungkin karena ketidaktahuan atau alasan lain secara tidak sengaja belum melaporkan harta dari penghasilan yang belum dikenakan pajak dalam SPT PPh (unintentionally non-compliant) maupun wajib pajak yang intentionally non-compliant untuk "berpindah" ke wajib pajak yang intentionally compliant atau dengan kata lain seorang yang wajib pajak yang tidak perlu memanfaatkan tax amnesty adalah mereka yang, entah sukarela atau terpaksa, telah menyelesaikan kewajiban pajak mereka. Sebagai contoh, seorang wajib pajak karyawan yang selama ini sudah dipotong dan memang sama sekali tidak memiliki penghasilan dari sumber lainnya namun, entah sengaja atau tidak sengaja, belum memasukkan harta tersebut ke dalam laporan SPT PPh, yang perlu dia lakukan adalah cukup melakukan pembetulan SPT PPh. Tidak perlu ikut program tax amnesty.

d. Tax amnesty dapat diimplementasikan di Indonesia, namun harus mempunyai payung hukum sebagai dasar serta tujuan yang jelas dalam pelaksanaan tax amnesty.

e. Secara sekilas, dalam jangka pendek dapat diketahui bahwa program tax manesty 2016 memberikan dampak yang signifikan terhadap kepatuhan pajak WP badan. Kondisi ini daat ditunjukkan dengan meningkatnya persentase tingkat kepatuhan wajib pajak di saat program amnesty pajak hendak berakhir yaitu di periode ketiga (30 Maret 2017). Artinya, pelaksanaan program tax manesty berpengaruh positif terhadap peningkatan jumlah kepatuhan wajib pajak.

f. Kekurangan dari penelitian ini adalah tidak adanya data pembanding yang tersedia untuk mengukur lebih jauh lagi tingkat pengaruh program tax amnesty terhadap kepatuhan wajib pajak badan dalam jangka panjang, sehingga ulasan akhir yang didapat tidak mencerminkan universalitas hasil penelitian untuk waktu yang akan datang.

g. Baik d Indonesia maupun di negara-negara yang pernah menerapkan program tax amnesty belum dapat menyimpulkan dengan pasti apakah pelaksanaan program tax amnesty dapat dijadikan indikator dalam menigkatkan kepatuhan pajak bagi warga negaranya.

\section{UCAPAN TERIMA KASIH}

Penulis mengucapkan terima kasih, menghargai dan menghormati Dr. H.K. PRIHARTONO AH., Drs., S.Sos., S.Komp., MM selaku Presiden Direktur Politeknik Piksi Ganesha Bandung atas diselenggaranya seminar nasional dan internasional dengan tema "Integrated Innovation and Communication Through New EnergyUsefulness in Business and Technology Sector". 


\section{DAFTAR PUSTAKA}

\section{Buku}

Abdul Asri Harahap, (2004), Paradigma Baru Perpajakan Indonesia, Perspektif Ekonomi-Politik, Integrita Dinamika Press.

Adelina, R. (n.d.). No Title, 1-20.

Adrian Sawyer, (2016), Targeting Amnesties at Ingrained Evasion - a New Zealand Initiative Warranting Wider Consideration?, Journal, Taxation and Bussiness Law, Department of Accountancy, Finance and Information Systems-University of Canterbury, http://www.austlii.edu.au/.

Alm, J., (1999), Tax compliance and administration. Public Administration and Public Policy, 72, 741 768.

Darussalam, (2015), Manfaatkan Pengampunan Pajak: Pahamai dan Manfaatkan Reinventing Policy. Inside Tax. Edisi 31,

James, S. \& Alley, C., (2004), Tax compliance, self-assessment, and tax administration. Journal of Finance and Management in Public Services, 2, 27-42.

Muttaqin, Zainal, (2013), Tax Amnesty di Indonesia, PT. Refika Aditama, Bandung

Ragimun. Analisis Implementasi Pengampunan Pajak (Tax Amnesty) di Indonesia.2014

Tambunan, R. Mengupas Sunset Policy \& Tax Amnesty, Senjata Kejar Target Pajak.2015

\section{Artikel Jurnal}

Bagiada, I. M., \& Darmayasa, I. N. (2016). Tax Amnesty Upaya Membangun Kepatuhan Sukarela. Simposium Nasional Akuntansi Vokasi V, 1-24.

Jamil, N. A. (2017). Efektivitas Penerapan Tax Amnesty di Indonesia, 1(1).

Rosid, A., \& Pendahuluan, A. (n.d.). Kepatuhan pajak dan tax amnesty, 1-11. 